\title{
The Open Economy Consequences of U.S. Monetary Policy
}

\author{
John C. Bluedorn \\ Christopher Bowdler ${ }^{\dagger}$ \\ (Nuffield College) \\ (Nuffield College) \\ john.bluedorn@economics.ox.ac.uk christopher.bowdler@nuffield.ox.ac.uk \\ Dept. of Economics, University of Oxford \\ Manor Road Building, Manor Road \\ Oxford OX1 3UQ \\ United Kingdom \\ Tel.: +44 (0) 1865-271-089 \\ Fax: +44 (0) 1865-271-094
}

July 2006

\begin{abstract}
A failure to identify movements in the federal funds rate that are both unpredictable and independent of other determinants of open economy variables may lead to attenuation bias in the estimated effects of U.S. monetary policy on the exchange rate and foreign variables. Using a U.S. monetary policy measure which isolates unpredictable and independent federal funds rate changes, we quantify the magnitude of the attenuation bias for the exchange rate and foreign variables. The exchange rate appreciation following a monetary contraction is up to 4 times larger than a recursively-identified VAR estimate. There is stronger evidence of foreign interest rate pass-through. The expenditure-reducing effects of a U.S. monetary policy contraction dominate any expenditure-switching effects, leading to a positive conditional correlation of international outputs and prices. We compare our results with those obtained using identification based upon: (1) non-recursive VAR restrictions; and, (2) restrictions derived from high frequency asset price behavior.
\end{abstract}

JEL Classification: E52, F31, F41

Keywords: open economy monetary policy identification, exchange rate adjustment, interest rate pass-through

\footnotetext{
†This paper is a major revision of Nuffield College Working Paper 2005-w18. The authors acknowledge financial support from British Academy post-doctoral fellowships. We would like to thank Roland Meeks, Maurice Obstfeld, and David Romer for valuable feedback. We would also like to thank seminar participants at the Federal Reserve Banks of Boston and St. Louis, the IMF, the Norwegian School of Economics and Business, Brunel University, the Royal Economic Society 2006 Annual Meeting, and the Universities of Oxford, Leicester, Warwick, Bristol, Southampton, and Essex. All errors are ours.
} 


\section{Introduction}

Since the final dissolution of the Bretton Woods system in 1973, bilateral exchange rate arrangements between the United States and the other G-7 nations have been predominantly characterized by flexible exchange rate regimes. In a flexible exchange rate world, the classic Mundell-Fleming-Dornbusch (MFD) model predicts that expansionary domestic monetary policy generates an exchange rate depreciation. Foreign interest rates are assumed to be exogenously set, and are thus unchanged. As a result of the exchange rate depreciation, the relative prices of Home goods fall, leading to an increase in the relative consumption of Home goods by domestic and foreign residents. The famous 'beggarthy-neighbor' effect ensues, with Home output rising and Foreign output falling. The increased purchasing power of Foreign currency leads to a fall in the Foreign price level, both from a direct valuation effect and from substitution within the Foreign consumption bundle towards Home goods.

The evidence for such a pattern of effects is mixed. There is a general consensus that expansionary U.S. monetary policy results in an eventual dollar depreciation, but the timing and magnitude of the depreciation varies across studies (e.g., Eichenbaum and Evans [1995]; Kim and Roubini [2000]; Faust, Rogers, Swanson, and Wright [2003]). The consequences of expansionary U.S. monetary policy for foreign interest rates, outputs and prices are more controversial. Foreign short rates are found to be completely unresponsive in some studies [Kim, 2001], while others indicate that foreign rates fall initially and then converge back to their long-run levels [Faust et al., 2003]. To the extent that foreign outputs and prices respond to U.S. monetary policy, their movements are often more consistent with a 'prosper-thy-neighbor' effect, counter to the logic of the classic model.

The primary policy target of the Federal Reserve since the early 1970s has been the federal funds rate, a market-based, overnight, interbank rate [Meulendyke, 1998]. ${ }^{1}$ Consequently, the majority of studies employ the federal funds rate as their measure of U.S. monetary policy. To consistently estimate the open economy consequences of

\footnotetext{
${ }^{1}$ A notable exception is the Volcker monetary growth targeting experiment from 1979-1981.
} 
U.S. monetary policy, it is important to identify federal funds rate changes which are: (1) unpredictable using the information set available to the market at the time of policy interventions; and, (2) independent of other determinants of open economy variables (e.g., inflationary supply shocks).

Unpredictability is necessary for identification since forward-looking and fast-moving variables such as the exchange rate and foreign interest rate can respond in advance of anticipated federal funds rate changes. Empirical work which gauges monetary policy effectiveness in terms of its contemporaneous and lagged impacts neglects responses based upon changes in expected future monetary policy, even though they are indicative of policy effectiveness. Such temporal decoupling attenuates the estimated exchange rate and foreign interest rate responses to federal funds rate changes. Independence is necessary for identification because some federal funds rate changes are endogenous to other variables which affect the exchange rate and foreign interest rate via channels unrelated to monetary policy. For example, U.S. policymakers may increase the federal funds rate in response to an inflation innovation. If the real exchange rate is mean-reverting, a depreciation of the nominal exchange rate will be required in order to offset the effects of higher domestic prices following the inflation innovation. This attenuates the exchange rate appreciation associated with an increase in the federal funds rate.

Foreign variables which are linked to the exchange rate will correspondingly show a weak response to U.S. monetary policy changes. For example, if foreign interest rates respond to the exchange rate, either directly as part of a managed float or indirectly through the expected impact of the exchange rate on foreign output and prices, attenuation bias in the exchange rate response will lead to a dampening of the reaction of foreign interest rates to U.S. monetary policy. Biases in the exchange rate and foreign interest rate responses then affect the estimated foreign output and price effects of U.S. monetary policy.

In this paper, we use the new monetary policy identification procedure introduced by Romer and Romer [2004] to estimate the open economy consequences of U.S. monetary 
policy. Romer and Romer combine information on the Federal Open Market Committee's (FOMC) intentions from the narrative records of its meetings with the Federal Reserve's Greenbook (in-house) forecasts of U.S. inflation, output growth, and unemployment. They then recover the component of intended federal funds rate changes around FOMC meetings that is orthogonal to the Federal Reserve's information set. We construct a daily-weighted, monthly average federal funds rate series from Romer and Romer's meetings-based series which exhibits the key properties of unpredictability and independence from alternative open economy determinants. Our principal contribution is to examine the responses of open economy variables to the resulting unpredictable and independent monthly average U.S. federal funds rate in six bilateral models (U.S. versus the other G-7 nations). We find that the peak effects of unpredictable and independent federal funds rate changes on bilateral U.S. dollar exchange rates are up to four times larger than those associated with recursively-identified innovations to the actual federal funds rate.

We also find that interest rate pass-through from the U.S. to other G-7 countries following unpredictable and independent federal funds rate changes is positive and larger than that observed following recursively-identified federal funds rate innovations. However, at horizons beyond two years, interest rate pass-through turns negative. We rationalize this observation by augmenting our models with a measure of predictable U.S. monetary policy which is shown to offset the effects of unpredictable and independent federal funds rate changes. The foreign interest rate tracks these stabilizing federal funds rate movements, generating negative interest rate pass-through at horizons of two to three years following an unpredictable change in the federal funds rate. Our results for foreign outputs and foreign prices are consistent with a prosper-thy-neighbor as opposed to a beggar-thy-neighbor effect - foreign outputs and prices are positively correlated with U.S. output and prices in the wake of unpredictable U.S. monetary policy. In contrast, prosper-thy-neighbor effects are either weak or absent following recursively-identified federal funds rate innovations. 
We compare our results with those recently obtained using alternative identification schemes based upon: (1) non-recursive (structural) VAR restrictions; and (2) VAR restrictions derived from high frequency asset price behavior. Specifically, we compare our open economy variable impulse responses to those of Kim and Roubini [2000] and Faust, Rogers, Swanson, and Wright [2003]. Kim and Roubini [2000] impose non-recursive, contemporaneous VAR restrictions to identify U.S. monetary policy innovations to the federal funds rate. Faust et al. [2003] identify U.S. monetary policy's effects from daily changes in exchange rate and interest rate futures and spot rates, using the estimated effects to restrict the impulse responses from a VAR. Our results are more consistent with Faust et al.'s broad findings in their partially identified VAR than they are with Kim and Roubini's non-recursively identified VAR. We are thus able to provide some cross-validation for U.S. monetary policy identification that is based upon high frequency asset price movements.

However, our analysis goes beyond validating results from alternative identification schemes. As the approach that we adopt is more readily implementable than that based upon high frequency data, we are able to demonstrate that monetary policy identification using information from outside the VAR matters for a broader range of bilateral US\$ exchange rates. Furthermore, we document new results concerning foreign short-term interest rates, foreign outputs and foreign prices. We also analyze the path of predictable U.S. monetary policy that follows an unpredictable U.S. monetary policy change, linking such behavior to open economy adjustment.

We carry out a series of robustness tests. We exploit the fact that the monetary policy changes are identified from outside the model to estimate impulse responses that allow for contemporaneous effects of monetary policy on each variable in the VAR, without assuming that the variables are linked by a particular recursive causal ordering. In addition, we augment the models with additional controls, vary the lag structure of the VAR, and undertake sub-sample sensitivity analysis. Overall, the results are robust to these perturbations. 
The paper proceeds as follows. In section 2, we briefly review theoretical work on the open economy consequences of monetary policy. We discuss the importance of the unpredictability and independence properties in monetary policy identification, explaining how the absence of these properties can lead to attenuation bias in the estimated effect of domestic monetary policy upon foreign variables. We then introduce our identification strategy and compare it with alternative schemes from the literature. In section 3, we describe our empirical methodology and the data employed. Then, in section 4, we present our results. We explore the robustness of our findings in section 5, and conclude with a brief summary and discussion in section 6 .

\section{Monetary policy and the open economy}

In this section, we first present a brief review of how domestic monetary policy affects open economy variables in theory. We then discuss monetary policy identification in the open economy context, describing how identification failures may lead to attenuation bias. We argue that the procedure advocated by Romer and Romer [2004] addresses the sources of identification failure in the open economy context. Finally, we close the section by comparing our open economy identification strategy with alternative approaches.

\subsection{Theoretical perspectives}

As mentioned in the introduction, the classic MFD model predicts a beggar-thy-neighbor effect of unanticipated domestic monetary policy - Home and Foreign outputs (and prices) are negatively correlated. These open economy effects of domestic monetary policy arise from the interaction of: (1) nominal rigidities; (2) the pure jump variable behavior of the exchange rate; and (3) complete exchange rate pass-through to traded goods' prices. Foreign monetary policy is assumed to be unreactive to domestic monetary policy changes.

Inaugurating the new open economy macroeconomics literature, Obstfeld and Rogoff [1995, 1996] constructed a micro-founded open economy macroeconomic model which 
incorporated nominal rigidities and monopoly distortions. Their analysis replicated the beggar-thy-neighbor effect (in terms of output responses) of unanticipated domestic monetary policy in the MFD model. However, they also demonstrated that expansionary domestic monetary policy is welfare-increasing for both Home and Foreign, as it mitigates monopoly distortions in the goods market and improves Foreign's terms-of-trade. Corsetti and Pesenti [2001] extended the model, showing that an unanticipated domestic monetary expansion may be Home welfare-decreasing if the accompanying terms-of-trade depreciation is sufficiently large. Foreign welfare unambiguously increases. The consequences for Foreign output depend upon the degree of consumption complementarity between Home and Foreign goods. If Home and Foreign goods are complements, then unanticipated domestic monetary policy generates a prosper-thy-neighbor effect. ${ }^{2}$

\subsection{The identification problem}

The accurate estimation of U.S. monetary policy's open economy effects requires that an empirical analogue to the theoretical concept of a monetary policy intervention be identified. Accordingly, the U.S. monetary policy measure employed must be: (1) unpredictable using the market's best information available at the time of intervention; and, (2) independent of other determinants of open economy variables.

To see the importance of identifying unpredictable federal funds rate changes, suppose that the market correctly anticipates a Federal Reserve interest rate increase in a quarter's time. In the absence of adjustment costs, agents should change their portfolios at the time at which information regarding the Federal Reserve's behaviour becomes known. The exchange rate then moves in advance of the federal funds rate, leading to attenuation bias when the estimated exchange rate response is a function of the contemporaneous correlation of exchange rate changes and actual federal funds rate changes. A simple Cagan-style model in which the exchange rate is related to the expected future

\footnotetext{
${ }^{2}$ In all of these models, the exchange rate behaves as a pure jump variable and exchange rate passthrough to prices is complete. There are several papers which relax these assumptions, such as Bacchetta and van Wincoop [2005] and Betts and Devereux [2000].
} 
path of monetary policy captures this intuition. A proper accounting of the impact of U.S. monetary policy on the exchange rate and foreign variables therefore requires that unpredictable U.S. interest rate changes be isolated.

In addition to being unpredictable, the federal funds rate changes employed must be independent of other open economy drivers. If they are not independent, then the estimation may suffer from an attenuating omitted variable bias. Consider the following simple, illustrative model:

$$
\begin{aligned}
y_{t} & =\alpha-\beta i_{t}+u_{t} \\
i_{t} & =\gamma+\zeta\left(y_{t}-\bar{y}\right)+e_{t} \\
\bar{p}_{t}-\bar{p}_{t-1} & =\phi\left(y_{t}-\bar{y}\right) \\
s_{t} & =\bar{s}_{t}=\bar{p}_{t} \\
\bar{y} & =\alpha-\beta \gamma \\
\gamma & =i^{*} .
\end{aligned}
$$

The variables here are: $y$, output; $i$, the monetary policy rate; $u$, the unpredictable output component; $\bar{p}$, the shadow (flexible) price level; $\bar{y}$, the natural level of output; $e$, the unpredictable and independent interest rate component; $s$, the exchange rate; and $i^{*}$, the exogenous foreign interest rate. Variables with overbars and time subscripts denote the shadow level of the variable. All parameters are denoted by Greek letters and are assumed to be positive. The equations here may then be interpreted as: (1) an IS curve; (2) a monetary policy reaction function; (3) a shadow Phillips curve; and (4) long-run purchasing power parity (a mean-reverting real exchange rate).

Substituting the monetary policy reaction function into the IS curve, we have that:

$$
\begin{aligned}
y_{t} & =\bar{y}-\left(\frac{\beta}{1+\beta \zeta}\right) e_{t}+\left(\frac{1}{1+\beta \zeta}\right) u_{t}, \text { and } \\
i_{t} & =\gamma+\left(\frac{1}{1+\beta \zeta}\right) e_{t}+\left(\frac{\zeta}{1+\beta \zeta}\right) u_{t} .
\end{aligned}
$$


The change in the exchange rate from last period is then given by:

$$
\begin{aligned}
s_{t}-s_{t-1} & =\bar{p}_{t}-\bar{p}_{t-1} \\
& =\phi\left(y_{t}-\bar{y}\right) \\
& =\phi\left[\bar{y}-\left(\frac{\beta}{1+\beta \zeta}\right) e_{t}+\left(\frac{1}{1+\beta \zeta}\right) u_{t}-\bar{y}\right] \\
& =-\left(\frac{\beta \phi}{1+\beta \zeta}\right) e_{t}+\left(\frac{\phi}{1+\beta \zeta}\right) u_{t} .
\end{aligned}
$$

Thus, the impact effect of the unpredictable and independent interest rate component $e$ is to appreciate the currency, while that of the unpredictable output component $u$ is to depreciate the currency. ${ }^{3}$ In contrast, both $e$ and $u$ increase the interest rate. Empirical work which mixes independent and dependent interest rate changes will result in attenuation bias in the exchange rate response to the federal funds rate. A biased exchange rate response in turn affects the estimated responses of foreign variables, such as interest rates, outputs and prices.

\subsection{A new measure of monetary policy}

The U.S. monetary policy measure that we employ builds upon the narrative approach to identification, which uses historical documentation to identify monetary policy changes. ${ }^{4}$ Romer and Romer [2004] (henceforth R\&R) have refined the use of narrative evidence by means of a two-step procedure applied to the United States' Federal Reserve Bank's monetary policy over the period 1969-1996. They employ the monetary policy measure thus derived to estimate how the U.S. economy responds to monetary policy.

In the first step, the narrative evidence is used to determine the size of the intended

\footnotetext{
${ }^{3}$ The different exchange rate effects of the two types of shocks are reminiscent of the analysis undertaken by Engel and Frankel [1984]. From the logic of the Fisher equation, they contend that the response of the exchange rate to nominal interest rate changes distinguishes expected inflation changes and real interest rate changes. For nominal interest rate increases, exchange rate depreciations indicate expected inflation increases, while exchange rate appreciations indicate real interest rate increases.

${ }^{4}$ The origins of the narrative approach date from Friedman and Schwartz's [1963] review of the monetary history of the United States. Romer and Romer [1989] formalized the approach in their analysis of FOMC meeting minutes to determine the dates of exogenous monetary policy contractions.
} 
change in the federal funds rate. Unintended federal funds rate changes may be caused by market fluctuations which are unrelated to Federal Reserve choices. In the second step, once the intended federal funds rate changes have been identified, they are decomposed into predictable and unpredictable components using real-time information on the current and expected future path of the U.S. economy. Specifically, R\&R regress the intended federal funds rate change upon the Greenbook forecasts of inflation, output growth, and unemployment available just prior to an FOMC meeting. These forecasts refer to horizons up to two quarters beyond the current quarter. ${ }^{5}$ They represent the Federal Reserve's central objective variables. ${ }^{6}$ The residuals from this regression are the federal funds rate target changes which are orthogonal to the Federal Reserve's forecasts. Romer and Romer [2000] showed that the Greenbook forecasts encompass alternative private-sector forecasts, indicating that the Greenbook forecasts are likely the most informative. This encompassing property of the Greenbook forecasts is important in that it ensures that the orthogonalization eliminates as much dependence in the intended federal funds rate as possible.

In our open economy investigation, the unpredictable and independent U.S. monetary policy measure is a daily-weighted monthly average series constructed from the FOMC meeting frequency data. Specifically, we take the regression residuals from $R \& R$ 's second step and cumulate them by days. The cumulated daily level series is then used to generate a monthly average unpredictable and independent federal funds rate measure. A similar procedure applied to the regression fitted values generates a monthly average predictable and dependent federal funds rate measure. ${ }^{7}$

\footnotetext{
${ }^{5}$ The forecasts used in the identification procedure outlined here are available in real-time, although the policy innovations could not have been generated in real-time because the first stage narrative evidence is evaluated ex post. See Croushore and Evans [forthcoming] for a discussion of the implications of real-time monetary policy identification.

${ }^{6}$ See Board of Governors of the Federal Reserve [2005] or the International Banking Act of 1978 (the Humphrey-Hawkins Act).

${ }^{7}$ Strictly speaking, the predictable component changes each day with new information and not just prior to FOMC meetings. This implies that in making the conversion from meeting frequency to monthly frequency data, predictable changes in the federal funds rate should be weighted according to the date at which they become predictable. However, such dates are unobserved, and therefore we use weights based upon the date at which the predictable change is implemented.
} 
To ensure independence in the open economy context, one might argue that the intended federal funds rate changes should be orthogonal to forecasts of future exchange rates and foreign variables. However, there are two arguments against such an approach. Firstly, the Federal Reserve generally does not target exchange rates or foreign variables directly [Meulendyke, 1998]. Furthermore, effective exchange rate forecasts are notoriously difficult to formulate. ${ }^{8}$ Secondly, exchange rates and foreign variables likely affect Federal Reserve decisions via inflation, output growth, and unemployment forecasts. However, this implies that the appropriate orthogonalization to be made is exactly the one undertaken: regress the intended federal funds rate on U.S. domestic economic forecasts and recover the residuals.

By orthogonalizing intended federal funds rate changes against the current and future forecast values of the Federal Reserve's central objective variables, the Federal Reserve's systematic interest rate response to the current and expected state of the U.S. economy is removed. The residuals then represent the unpredictable and independent component of federal funds rate changes, corresponding to the open economy thought experiment alluded to in section 2.1. Some predictability and dependence likely remains in the monetary policy measure due to the exclusion of some variables and forecast horizons from the orthogonalization. In the event that the new monetary policy measure still contains predictable and/or dependent components, the magnitudes of the estimated open economy effects represent a lower bound for the true effects.

\subsection{Other identification approaches}

We close this section with a discussion of alternative approaches to open economy monetary policy identification, describing some of their results. In section 4, we will compare our results with those outlined here.

Many of the papers which estimate the open economy consequences of U.S. monetary policy fit a VAR for a system of open economy variables. Monetary policy changes are

\footnotetext{
${ }^{8}$ This is famously demonstrated by Meese and Rogoff [1983].
} 
identified by imposing restrictions upon the behaviour of the system's unobserved innovations. Most commonly, the contemporaneous linkages between variables are restricted so that a Wold causal chain may be defined (a recursive identification scheme). ${ }^{9}$ The canonical open economy example of such an identification approach is Eichenbaum and Evans' [1995] paper, which considers the U.S. versus the non-U.S. G-7 in a set of bilateral VARs. Monetary contractions in the U.S. are shown to appreciate the US\$, although the time until the maximum appreciation is up to three years in some cases.

Kim and Roubini [2000] argue that the short-run restrictions implied by a recursive identification scheme are likely invalid for the open economy. They identify U.S. monetary policy by assuming that the federal funds rate responds only to its own innovation and to innovations in the world oil price. In contrast to Eichenbaum and Evans's study, the foreign interest rate is allowed to respond contemporaneously to exchange rate movements. The maximum exchange rate appreciation associated with a 100 basis point federal funds rate innovation ranges from $0.6 \%$ to $1.8 \% .{ }^{10}$ Foreign interest rates show a generally positive response, with the maximum pass-through ranging from $20 \%$ to $62 \%$. Foreign output and prices generally rise in response to a U.S. federal funds rate increase, albeit only weakly. The maximum foreign output increase ranges from approximately $0.15 \%$ to $0.6 \%$, gradually declining and becoming negative at more distant horizons. The maximum foreign price increase ranges from $0.35 \%$ to $0.6 \%$, typically staying positive and asymptoting to zero. ${ }^{11}$

Faust, Rogers, Swanson, and Wright [2003] follow Kuttner [2001] by employing changes in federal funds rate futures' prices around FOMC meetings to identify unpredictable U.S. monetary policy changes. Using high frequency data, they regress observed changes in the exchange rate and the prices of one, three and six month-forward federal funds rate and foreign interest rate futures on the change in the federal funds rate target at the

\footnotetext{
${ }^{9}$ The Wold causal chain is reflected in the ordering of the variables in a recursive VAR, as this order affects the Choleski decomposition of the covariance matrix [Sims, 1980].

${ }^{10}$ See Kim and Roubini [2000], Figure 4.

${ }^{11}$ Their estimated UK price response shows a dramatic, persistent decline, counter to the other countries' responses.
} 
time of the FOMC announcement. If exchange rates and asset prices embody market expectations and if risk premia are constant, the fitted values from such a regression give the effects of an unpredictable change in the federal funds rate at horizons of zero, three and six months for the respective variables. Eichenbaum and Evans' [1995] open economy VAR is then identified by assuming that monetary policy in the monthly data replicates the effects identified from the high frequency data regressions. The remainder of the VAR's contemporaneous relationships are partially identified, using the procedure outlined in Faust and Rogers [2003]. Faust et al. [2003] are then able to bound the likely impulse responses. Due to high frequency data limitations, they only consider the U.S.'s bilateral relationships with Germany and the United Kingdom. ${ }^{12}$ In response to a 100 basis point federal funds rate innovation, Faust et al. find a maximum exchange rate appreciation which ranges from $1 \%$ to $7.2 \%$ for Germany and $1 \%$ to $4 \%$ for the UK. The maximum foreign interest rate pass-through ranges from $20 \%$ to $80 \%$ for Germany and $40 \%$ to $120 \%$ for the UK. There is an initial foreign output rise, but this is quickly reversed. The predominant response to a federal funds rate increase is a foreign output reduction, counter to that reported by Kim and Roubini [2000]. The maximum output decline ranges from $0.2 \%$ to $1.2 \%$ for Germany and $0.2 \%$ to $1.6 \%$ for the UK.

\section{Econometric methodology and data}

In order to gauge the impact of U.S. monetary policy in the open economy, we estimate a set of six bilateral open economy VARs (U.S. versus the non-U.S. G-7). ${ }^{13}$ The baseline VAR specification we employ is:

$$
\left[y, p, y^{*}, p^{*}, r, r^{*}, s\right]^{\prime},
$$

\footnotetext{
${ }^{12}$ The high frequency asset price identification procedure requires highly liquid markets in a variety of financial instruments.

${ }^{13}$ The non-U.S. G-7 includes: Canada; France; Germany; Italy; Japan; and the United Kingdom. Their respective currencies are denoted: CN\$; FRF; GRM; IT£; JP¥; and UK£.
} 
where $y$ is the $\log$ of a U.S. industrial production index, $p$ is the log of the U.S. CPI, $y^{*}$ is the $\log$ of a foreign industrial production index, $p^{*}$ is the log of a foreign price index, $r$ is the U.S. short-term policy rate, $r^{*}$ is the foreign short-term interest rate, and $s$ is the bilateral dollar exchange rate. The exchange rate is defined as the US\$ price of one unit of foreign currency, so that a fall in the exchange rate is a US $\$$ appreciation. The VAR includes a full set of monthly dummies and each variable enters with 12 lags. ${ }^{14}$ The VAR is estimated with monthly data which covers the period from 1969-1996. ${ }^{15}$ A full description of data sources is provided in the appendix.

Figure 1 depicts: the actual federal funds rate $(\mathrm{FF})$; the unpredictable, independent component of the federal funds rate (UM); and the predictable, dependent component of the federal funds rate (PM). The construction of UM and PM was described earlier in section 2.3. The series are normalized to start at zero. As can be seen, there are important differences across the series, with the predictable, dependent component of monetary policy being much more closely related to the actual federal funds rate's movements than the unpredictable, independent component. Our baseline comparison considers the above VAR with either FF or UM as the U.S. interest rate measure $r$.

In calculating impulse response functions, we first assume a recursive causal ordering, allowing the effects of orthogonal changes in FF and UM to be compared. The ordering is given by the sequence of variables listed above, and reflects the belief that financial market variables should be treated as most endogenous because they typically move faster than goods market variables. Given the leading role played by the U.S. in international financial markets, we place the U.S. interest rate above the foreign interest rate and the exchange rate in the ordering. This means that foreign interest rates may respond contemporaneously to U.S. interest rates. Previous work has shown that it is important to allow for this possibility [Faust and Rogers, 2003]. Our results are robust to plausible

\footnotetext{
${ }^{14}$ Although many previous studies have employed 6 lags, we find that the shorter lag structure leads to residual autocorrelation and heteroscedasticity. This problem is rectified by using the longer lag structure. The appendix provides a full set of VAR residual diagnostic tests. In section 5.3, we discuss results based on VARs containing 6 lags.

${ }^{15}$ Exact estimation periods vary by country according to data availability. In general, the full sample is 1972:1 to 1996:12, except for the United Kingdom (1973:1 to 1996:12) and Canada (1976:1 to 1996:12).
} 
alternative orderings. Furthermore, in section 5, we exploit the fact that UM is identified outside the VAR to obtain results that do not assume any recursive causal ordering but which still allow for contemporaneous effects of U.S. monetary policy upon each of the variables. These results are remarkably similar to our baseline results for UM.

The standard errors given for the impulse responses are calculated analytically via the delta-method. Even though the U.S. monetary policy measure is a generated regressor, hypothesis testing versus a null of no effect is still valid [Pagan, 1984]. ${ }^{16}$ All impulse response lines represent the percentage point response of the variable level to an orthogonalized 100 basis point (b.p.) U.S. interest rate measure innovation.

\section{Empirical results}

We now present the set of impulse responses from the baseline VAR, considering: (1) the exchange rate; (2) the foreign interest rate, output and price level; and (3) U.S. output and prices. We close the section by describing how the predictable, dependent component of U.S. monetary policy responds in an augmented version of the baseline VAR.

\subsection{Exchange rate responses}

In Figure 2, we present the response of bilateral U.S. dollar exchange rates to FF and UM. In the upper panel of Table 1, we report the percentage deviation in the exchange rate (from its initial level) that has maximum absolute value over 12 and 48 month horizons.

An inspection of the results reveals that the identification of unpredictable and independent federal funds rate innovations from outside the VAR has important consequences. Excepting the case in which Canada is the foreign country, the US\$ exchange rate traces out a more pronounced U-shape following a UM innovation than it does following an FF innovation, appreciating at a faster rate during the first 12 months and then later

\footnotetext{
${ }^{16}$ For comparison, we also calculated bootstrapped standard errors for the U.S.-Japan VAR, which do correct for the presence of a generated regressor. Specifically, we employed a residual bootstrap with 500 replications. The bootstrapped and delta-method based standard errors were virtually identical.
} 
reverting to its long-run level. ${ }^{17}$ The quantitative differences in the results are large. The maximum US\$ appreciation observed within the first year after a UM innovation is generally twice that observed in response to an FF innovation, and is more than eight times as large in the case of the US\$/JP¥ exchange rate. A comparison of our results with those from Kim and Roubini [2000]'s non-recursive VAR identification highlights similar differences. Exchange rate responses to UM are larger than those reported by Kim and Roubini in all cases, except when Canada is the foreign country. When Japan is the foreign country, they are more than five times as large. One explanation for these differences is that exchange rate responses to predictable and dependent movements in the federal funds rate are subject to attenuation bias, as argued in section 2.2 , and that such movements in the federal funds rate are not completely accounted for by non-recursive identification schemes.

The exchange rate responses to a UM innovation are consistent with the impulse response bounds for the US\$/UK£ and US\$/GRM presented by Faust et al. [2003]. According to our results, an unpredictable and independent 100 b.p. federal funds rate increase appreciates the US\$/UK£ exchange rate by $0.59 \%$ and the US\$/GRM exchange rate by $1.04 \%$ within the first month. These estimates are within Faust et al.'s bounds, although somewhat below the midpoints, which are approximately $2.1 \%$ and $3.8 \%$ respectively. ${ }^{18}$ The overall maximum exchange rate responses that we estimate are also within Faust et al.'s bounds, exceeding the midpoint in the case of the US\$/UK£ rate and equaling the midpoint in the case of the US\$/GRM rate. Such coincidence from two different identification schemes is reassuring. Furthermore, our results indicate that the magnitude of the exchange rate responses estimated by Faust et al., which are much larger than those previously reported in the literature, are observed for bilateral US\$ exchange rates other than those versus the UK£ and the GRM.

\footnotetext{
${ }^{17}$ The weak response of the US\$/CN\$ exchange rate appears to be due to Canadian interest rates adjusting rapidly to U.S. interest rates, so that interest rate differentials and the scope for exchange rate adjustment are short-lived.

${ }^{18}$ The latter figures are based on an inspection of Faust et al.'s Figures 3 and 4, scaled such that they correspond to 100 b.p. innovations.
} 
We also calculated forecast error variance decompositions (FEVD) for the exchange rate. In some cases, they indicate that the proportion of exchange rate variance attributable to U.S. monetary policy increases when predictable and dependent policy changes are removed. For example, when Japan is the foreign country this figure increased from $1.9 \%$ to $14.5 \%$ for the 12 month horizon. However, in most cases the explanatory power of UM for the exchange rate was similar to that of FF. ${ }^{19}$ Although the unpredictable, independent federal funds rate component elicits larger exchange rate responses, the variation of the series is smaller than the variation in the actual federal funds rate, implying that the overall explanatory power of the two is comparable. As such, our results do not suggest that the fraction of historical exchange rate fluctuations attributable to monetary policy is any greater than previously believed, but rather that unpredictable and independent movements in the federal funds rate have the potential to explain relatively large exchange rate changes.

\subsection{Foreign adjustment to U.S. monetary policy}

In Figure 3, we present the responses of foreign interest rates to FF and UM. In the lower panel of Table 1, we summarize information on the maximum absolute foreign interest rate changes observed at 12 and 48 month horizons. The picture that emerges is that UM innovations result in much higher rates of interest rate pass-through to the other G-7 countries. A candidate explanation for these results is linked to the pattern of exchange rate responses that we have documented. Specifically, foreign interest rate adjustment may be a direct reaction to exchange rate movements vis-à-vis the U.S. (e.g., in the case of a 'managed float' of the currency). Alternatively, it may be an indirect reaction. For example, a US\$ appreciation may increase foreign expected inflation and output growth via expenditure-switching, prompting increases in foreign interest rates. To the extent that predictable and dependent federal funds rate increases induce relatively weak US\$ appreciation, the pressure for increases in foreign interest rates will be muted. This

\footnotetext{
${ }^{19}$ Full FEVD results are available upon request.
} 
provides a potential explanation for the larger responses of foreign interest rates to UM.

The foreign interest rate responses that we estimate are typically three times larger than those reported by Kim and Roubini using a non-recursive identification scheme. On the other hand, our results are broadly in-line with those estimated by Faust et al. using information from high frequency data. ${ }^{20}$ For example, the contemporaneous effects that we estimate are 0.35 for the UK and 0.17 for Germany, and are in the middle of Faust et al.'s bounds. The peak effects that we estimate are approximately equal to the upper bound in the case of the UK, and about one third larger than the upper bound in the case of Germany. These results suggest that direct interest rate linkages are an important channel in international business cycle propagation. This contrasts with Kim [2001], who finds little evidence of direct pass-through from the federal funds rate to other short-term interest rates. He argues instead that international financial linkages operate via the world long-term real interest rate.

An interesting feature of the response of foreign interest rates to UM innovations is the negative reaction observed at long horizons, which causes the impulse response line to follow a rotated inverse S-shape. An inspection of the U.S. monetary policy authority's response to UM suggests a possible explanation. In section 4.4, we present results from VARs augmented with the predictable, dependent component of the intended federal funds rate $(\mathrm{PM})$. We find that a UM innovation induces an opposite-signed adjustment in PM, likely to offset the effects of unpredictable interest rate changes on output and inflation. The predictable federal funds rate response to a UM innovation is mirrored in foreign interest rate responses. Such a correlation is consistent with either: (1) the direct transmission to foreign rates of predictable U.S. rate changes which follow a UM innovation; or (2) an indirect response of foreign rates arising from the foreign output and price effects which follow a UM innovation. Consequently, at long horizons interest rate pass-through following an unpredictable and independent U.S. monetary policy change is negative.

\footnotetext{
${ }^{20}$ The foreign interest rates that we consider are money market rates, whereas Faust et al. consider treasury-bill rates.
} 
In Figures 4 and 5, we present impulse responses for foreign output and foreign prices. In Table 2, we summarize information on the maximum changes in these variables observed at 12 and 48 month horizons. Following a U.S. monetary policy contraction, each of the other G-7 countries experiences a recession, indicating that the direct expenditurereducing consequences of positive interest rate pass-through dominate any expenditureswitching effects associated with foreign currency depreciation. ${ }^{21}$ These prosper-thyneighbor effects are somewhat larger than those previously documented. The maximum foreign output response found by Kim and Roubini following a 100 b.p. U.S. tightening entails a $0.87 \%$ reduction in output, with most of the foreign recessions being insignificant at the $5 \%$ level. The largest foreign recession induced by UM entails a $3 \%$ output reduction; the median reduction is $1.63 \%$. The maximum output response that we estimate for the UK exceeds the upper bound for UK output reported by Faust et al., while the maximum response that we estimate for Germany is slightly smaller than the upper bound reported by those authors. The peak effects that we estimate occur after 14 months for the UK and 20 months for Germany, whereas the upper bound on the peaks reported by Faust et al. occur after approximately three years. Thus, UM exerts relatively powerful effects on foreign output in the first two years.

Turning to the results for the foreign price level, we see that the responses to a UM innovation are larger than those to an $\mathrm{FF}$ innovation. In particular, an unpredictable and independent federal funds rate increase brings about a reduction in the price level that is significant at the $5 \%$ level in 3 of the 6 foreign countries. An actual federal funds rate increase does not induce such a change in any of those countries. Our results differ from those reported by Kim and Roubini. They find that the largest reduction in foreign prices following a 100 b.p. monetary contraction is $0.58 \%$, whereas the largest reduction in foreign prices that we estimate is $3.96 \%$, with a median of $1.00 \%$. Furthermore, Kim and Roubini's results indicate that the price increases observed in some countries following a U.S. monetary policy contraction can last more than four years, and are at least as big

\footnotetext{
${ }^{21} \mathrm{~A}$ recession in the U.S. may be propagated internationally via other mechanisms. For example, reduced demand in the U.S. may feed through to other countries via trade linkages.
} 
as the price reductions observed in other countries during the four years that follow a contraction. In contrast, we find that the evidence for foreign prices increases following a UM innovation is mainly limited to the first year or two following a shock, and that any increases in foreign prices are small relative to the price reductions that occur in other countries.

\section{$4.3 \quad$ U.S. price and output responses}

The responses of U.S. prices and output to unpredictable and independent monetary policy changes identified by Romer and Romer are investigated by them. However, most of the evidence presented in Romer and Romer [2004] is based on single equation models. They do consider one three variable VAR (comprising output, prices and interest rates) that is estimated with 36 lags. The open economy VARs that we consider are richer, with a lag structure which is more typical of the literature.

Figure 6 presents impulse response functions for U.S. output. In all six cases, the reduction in U.S. output associated with a UM innovation exceeds that associated with an FF innovation. This confirms R\&R 's findings from a 3-variable VAR with 36 lags. The most striking feature of our results is the speed with which a UM innovation affects the economy. The average time to maximum output reduction is about 12 months, approximately half the time estimated by R\&R. Cochrane [2004] argues that the 24 month lag until the maximum negative output effect of monetary policy estimated by $\mathrm{R} \& \mathrm{R}$ is problematic, because existing theoretical models are generally unable to explain such lags. From this perspective, the reduction in time to maximum negative output response which we find is important. ${ }^{22}$

In Figure 7, we present impulse response functions for the U.S. CPI. An FF innovation leads to a persistent increase in consumer prices. This is the price puzzle noted by Sims [1992]. In contrast, any price puzzle associated with a UM innovation is small and

\footnotetext{
${ }^{22}$ It is also interesting to note that the delay in the response of U.S. output estimated by Faust et al. is 24 months, coinciding with Romer and Romer [2004].
} 
eliminated within a few months. The expected CPI decline then begins after about one year. After 24 months, the time at which downward price adjustment begins in R\&R's analysis, the reduction in prices is generally significant at the $5 \%$ level and is between one half and two thirds the total change observed after four years. ${ }^{23}$ Hence, not only is a price puzzle avoided by employing an intended and unpredictable federal funds rate innovation in the VAR analyzed in this paper, but the time until the onset of deflation is greatly reduced relative to that found by $R \& R$. This finding suggests that the delays in price adjustment that need to be explained in theoretical work are much smaller than previously believed.

Experiments with alternative VAR models indicated that the main reason for the faster output and price adjustment relative to $R \& R$ is the reduction in the number of lags included in the model, from 36 to 12 . We found no evidence to support the view that the inclusion of open economy variables in the model drives the new pattern of U.S. output and price responses.

\subsection{Interactions with predictable monetary policy}

In this sub-section, we augment the baseline model with the measure of predictable, dependent monetary policy $(\mathrm{PM})$ that we constructed from the fitted values generated in the second stage of R\&R's identification procedure. This variable is included as the sixth variable in an expanded eight variable VAR that otherwise preserves the recursive ordering previously described. Figure 8 shows how the predictable, dependent component of U.S. monetary policy responds to the unpredictable, independent component of U.S. monetary policy. The dominant response of PM is negative, often with a magnitude comparable to the initial 100 b.p. increase in UM. Thus, after a UM innovation, the predictable and dependent component of U.S. monetary policy moves in a manner which stabilizes the overall intent of monetary policy. An interpretation of this pattern follows. Unpredictable

\footnotetext{
${ }^{23}$ Faust et al.'s identification scheme mitigates the price puzzle associated with U.S. monetary policy contractions, but does not yield reductions in the U.S. price level that are significant at the $5 \%$ level.
} 
and independent changes in monetary policy often reflect the private beliefs of FOMC members concerning the future direction of the U.S. economy. Such private beliefs are not embodied in Greenbook forecasts and therefore provide a source of exogenous monetary policy movements. In the event that these beliefs are later shown to be incorrect (output growth and inflation deviate from target), the Federal Reserve implements predictable, offsetting changes in monetary policy in order to stabilize the economy. ${ }^{24}$

This view of the interaction between predictable and unpredictable monetary policy has at least two important implications for the results discussed in this paper. Firstly, the textbook experiment of an exogenous, sustained monetary policy contraction is unlikely to ever be observed in practice. Even an unpredictable and independent U.S. monetary policy change is followed by offsetting movements in predictable U.S. monetary policy. This potentially limits the peak estimated effect of monetary policy on variables such as output, prices and the exchange rate, because the monetary policy intervention is shortlived. A counterfactual exercise in which the stabilizing effects of predictable monetary policy are absent may indicate that the share of macroeconomic fluctuations attributable to monetary policy is greater than currently believed. Secondly, as noted in our discussion of foreign interest rate dynamics, the negative interest rate pass-through observed at long horizons following a UM innovation may reflect the foreign interest rate response to the predictable movements in the federal funds rate that follow an unpredictable and independent U.S. monetary policy change.

\section{Robustness}

We now investigate the robustness of our results. The extensions of our baseline procedure that we consider are: (1) alternative recursive VAR identification schemes (orderings); (2) the inclusion of additional controls; (3) an alternative lag structure; and (4) estimating the model over different sub-samples.

\footnotetext{
${ }^{24}$ Such offsetting moves in response to random changes in monetary policy are an important part of Engel and Frankel's [1984] model.
} 


\subsection{Alternative recursive VAR orderings}

It is well known that the results obtained from recursive VAR identification schemes may be sensitive to the particular variable ordering. Faust and Rogers [2003] present evidence on this issue from an open economy VAR. They draw particular attention to the likely simultaneity between financial market variables such as the domestic and foreign interest rates and the exchange rate. In the present context, unpredictable federal funds rate movements which are independent of other open economy drivers are separately identified by the $R \& R$ procedure, using narrative evidence and Greenbook forecasts. They are therefore more likely to be exogenous with respect to foreign interest rates and the exchange rate. ${ }^{25}$ A logical variation on the baseline VAR ordering is therefore to place $r(\mathrm{UM})$ at the top of the system. This allows for U.S. monetary policy to have contemporaneous effects on all of the variables. It also means that the responses to U.S. monetary policy innovations will be invariant to the ordering of variables further down the VAR, including the other financial variables (since they are irrelevant to the policy innovation decomposition). Our main results are robust in this setting, especially those for bilateral US $\$$ exchange rates and foreign interest rates. The response of foreign output increased slightly in some cases. For example, the reduction in Japanese output following a UM innovation was $1.25 \%$, a deeper recession than that obtained in the baseline case. This may be due to the fact that the alternative VAR specification allows for UM to exert a contemporaneous effect on foreign output. Foreign price responses were largely unchanged using the alternative VAR ordering.

A second option that we can pursue using the unpredictable and independent federal funds rate measure avoids imposing any recursive structure. Specifically, we estimated a model that allows for direct contemporaneous effects of U.S. monetary policy on each of the other variables. This is accomplished by adding the current dated value of $r$ (UM)

\footnotetext{
${ }^{25}$ This assumes that the Federal Reserve does not set interest rates in response to foreign interest rates and the exchange rate. Romer and Romer [2004] argue that this is generally the case, but note an exception to the rule in the six month period spanning the final quarter of 1984 and the first quarter of 1985. We address this possibility in section 5.4.
} 
to each equation in the VAR model (excepting the equation for the U.S. interest rate) and then generating impulse responses by considering innovations to the reduced form equation for UM. Since unpredictable U.S. monetary policy changes are identified with information from outside the VAR, such an approach is feasible. In general, the results that we obtained were very similar to those from the baseline exercise. A noteworthy finding was that the contemporaneous effects of UM on the exchange rate and foreign interest rates were closer to the midpoints of the bounds for those responses reported by Faust et al.. Overall, our findings concerning the effects of unpredictable and independent federal funds rate changes do not appear to depend upon particular aspects of the recursive VAR identification employed.

\subsection{Additional controls}

Sims [1992] argues that increases in commodity prices often raise inflation, leading to higher nominal interest rates. A commodity price index can act as an 'information variable' that controls for these episodes, potentially mitigating the price puzzle and other anomalies associated with federal funds rate innovations. To address this possibility, we included the log level of the commodity price index from the International Monetary Fund's International Financial Statistics (IFS) as the fifth variable in the estimated VARs. This ordering reflects the approach taken by Kim [2001]. We summarize the main findings here. $^{26}$

The exchange rate responses that we estimated were generally consistent with those from the baseline models. In the case in which Germany is the foreign country, the difference between the maximum US\$ appreciations associated with a UM innovation and an FF innovation narrowed slightly. In other cases, the maximum appreciation associated with a UM innovation fell relative to the baseline estimates. However, the maximum appreciation associated with an FF innovation also fell, such that the difference between the two was preserved. For example, the maximum appreciations for the US\$/UK£ rate

\footnotetext{
${ }^{26}$ Full details of the additional results discussed are available upon request.
} 
were $3.1 \%$ after a UM innovation and $1.4 \%$ after an FF innovation. The corresponding figures from the baseline results were $4.2 \%$ and $2.2 \%$ respectively. These changes reflect the fact that some exchange rate movements previously attributed to monetary policy are now attributed to commodity price fluctuations.

We observed some reductions in interest rate pass-through following a UM innovation in those cases in which either Italy or the United Kingdom was the foreign country. However, in the other four cases the levels of interest rate pass-through seen in the baseline results proved robust. This finding is contrary to the claim in Kim [2001] that controlling for commodity prices eliminates interest rate pass-through from the U.S. to the other G-7 countries, through absorbing common shocks to world interest rates. The foreign output and price responses generally changed very little relative to the baseline estimates.

A second extension of the information set in the baseline VAR involved adding a time trend to each equation. Giordani [2004] showed that the removal of the underlying trend from variables such as output can eliminate the price puzzle associated with the federal funds rate. The main changes in our results were reductions in the price rises observed in the U.S. and the foreign country following an FF innovation in the bilateral VARs with France, Germany and Italy. This finding is consistent with the results in Giordani [2004]. However, in each of these cases the deflationary effects of a UM innovation remained much stronger than the deflationary effects of an FF innovation. When Canada, Japan or the United Kingdom was the foreign country, the dominant responses of U.S. and foreign prices to $\mathrm{FF}$ innovations were positive, whilst the dominant responses to UM innovations were negative. Finally, the responses of the two financial market variables, namely the bilateral US\$ exchange rate and the foreign interest rate, changed little with the addition of a time trend. 


\subsection{An alternative lag structure}

Open economy VAR models fitted using monthly data often feature 6 lags rather than 12. In section 3, we noted that 12 lags are required to remove evidence of residual serial correlation and heteroscedasticity. Nevertheless, we estimated each of the models using 6 lags in order to judge the sensitivity of our results along this dimension. Our findings were robust in most cases. However, in the VAR where Germany was the foreign country, the maximum responses of the exchange rate, the foreign interest rate and foreign output to a UM innovation decreased relative to the baseline case; they were much closer to the estimated responses to an FF innovation. There was also some narrowing of the gap between the peak exchange rate responses to UM and FF in the models where France and Italy were the foreign countries. Hence, our main results are slightly weaker when the empirical models are fitted using 6 lags rather than 12. However, we stress that our core results are associated with the more general lag structure, and that the restricted lag structure induces serial correlation and heteroscedasticity in the residuals.

\subsection{Sub-sample stability}

The final part of our robustness analysis is based on sub-sample regressions. Romer and Romer [2004] note that during the early stages of Volcker's chairmanship of the Federal Reserve, policy was often implemented by targeting quantities (the level of non-borrowed reserves) rather than the federal funds rate. This experiment lasted until June 1981. Thus, we fitted the baseline VARs for the period 1982:6-1996:12, so that no observations prior to 1981:7 are used in the estimation. This sub-sample also excluded the turbulent years of the 1970s. The second sub-sample for which we estimated the VARs begins at the same time as the core sample and ends in 1992:8. This led to the exclusion of the exchange rate crises that saw the UK£ and the IT£ drop out of the European Exchange Rate Mechanism (ERM) and the bands for the FRF/GRM rate widened.

The key points are as follows. Firstly, during the post-1982:6 period both U.S. mone- 
tary policy measures generated exchange rate responses that were larger than those estimated using the full sample. For example, the US\$/JP¥ rate appreciated $16 \%$ following a UM innovation, and 7\% following an FF innovation. In general, during the post-1982:6 period, exchange rate responses to UM innovations were larger than the responses to FF innovations, with an exception where France was the foreign country. Turning to the responses of foreign interest rates, higher interest rate pass-through in response to UM innovations were observed in the post-1982:6 sub-sample. The French results again were exceptional, yielding equal interest rate pass-through for the two U.S. monetary policy measures.

The foreign price and output responses that we estimated using the post-1982:6 period were less robust than the financial variable responses. Following a UM innovation, there was little evidence of a foreign recession in Italy or Japan, and persistent price increases were observed for Canada and Germany. One reason for these results may be that estimating the responses of output and prices to monetary policy requires longer spans of data than does estimating the responses of financial market variables, since the former are relatively slow-moving and complete only a small number of cycles during the 14 years covered by the sub-sample.

The results that we obtained using a sub-sample ending in 1992:8 were much closer to the full sample results for each of the variables, reflecting the fact that the sample was trimmed by a smaller amount in this case. Importantly, the responses of US $\$$ exchange rates versus the FRF, IT£ and the UK£ did not change very much after excluding the period in the 1990s, in which there was some turbulence in European interest rates and exchange rates.

The final issue that we addressed was the importance of the six month period spanning the final quarter of 1984 and the first quarter of 1985. As noted previously, there is some evidence that during this time the Federal Reserve adjusted the federal funds rate in response to the value of the US\$. In this case, the unpredictable and independent federal funds rate measure that we consider may be predicted by and dependent upon 
the exchange rate. We re-estimated each of the baseline VARs after including six impulse dummies for the months in question, but did not observe any important changes in our core results. ${ }^{27}$

\section{Conclusion}

We have argued that predictable and dependent movements in the federal funds rate lead to attenuation bias in the estimated effect of U.S. monetary policy on the exchange rate and foreign interest rates, outputs and prices. We investigated this argument by estimating the open economy consequences of a new U.S. monetary policy measure based upon the work of Romer and Romer [2004]. The monetary policy identification procedure isolates unpredictable federal funds rate changes which are independent of other open economy drivers by combining narrative evidence on Federal Reserve intentions with the information embodied in the Federal Reserve's Greenbook forecasts. Our results indicate that unpredictable and independent federal funds rate changes exert much larger effects on bilateral US\$ exchange rates and foreign interest rates than do actual federal funds rate changes (on average 2.5 times larger and 1.75 times larger respectively). We also find larger prosper-thy-neighbor foreign output and price effects in response to unpredictable and independent U.S. monetary policy, potentially indicating that the expenditure-reducing effects of interest rate pass-through overwhelm the expenditureswitching effects of exchange rate depreciation.

A comparison of our results with those from alternative identification schemes revealed: (1) little support for the results obtained using non-recursive VAR restrictions; and (2) a general concordance with the results from VAR restrictions derived from high frequency asset price behaviour. As the identification strategy that we employ is more readily implemented than that based upon high frequency asset price-based VAR restric-

\footnotetext{
${ }^{27}$ Strictly speaking, given that the VAR is of order 12 the model should include 12 lags of each of the impulse dummies in order to completely remove the six problematic observations from the likelihood function. However, the resulting parameter profligacy would lead to a substantial reduction in the effective degrees of freedom.
} 
tions, we are able to estimate the effects of U.S. monetary policy for a broader range of countries. These estimates proved robust along several dimensions, including alternative recursive VAR orderings, the addition of other information variables, and the use of various sub-samples.

For future research, our analysis has at least three important implications. Firstly, when estimating the international effects of monetary policy, it is necessary to identify policy changes which are unpredictable and independent of other open economy drivers. For example, this point is relevant for the literature which assesses German monetary policy's influence upon European business cycles. Secondly, bilateral open economy models should be capable of generating large and positive interest rate pass-through from the U.S. to the foreign country, as such a channel is critical to the international transmission of U.S. monetary policy. Thirdly, the estimated effects of U.S. monetary policy upon open economy variables, against which simulation results from calibrated open economy models may be compared, are larger than previously believed. 


\section{References}

Philippe Bacchetta and Eric van Wincoop. Rational inattention: A solution to the forward discount puzzle. NBER Working Paper, (11633), September 2005.

Caroline Betts and Michael B. Devereux. Exchange rate dynamics in a model of pricingto-market. Journal of International Economics, 50(1):215-244, February 2000.

Board of Governors of the Federal Reserve. The Federal Reserve System Purposes and Functions. Publications Fulfillment, Board of Governors of the Federal Reserve, Washington, D.C., ninth edition, June 2005.

John H. Cochrane. Comments on "A new measure of monetary shocks: Derivation and implications" by Christina Romer and David Romer. URL http://gsbwww.uchicago.edu/fac/john. cochrane/research/

Papers/talk_notes_new_measure_2.pdf. Presented at NBER EFG meeting, July 2004.

Giancarlo Corsetti and Paolo Pesenti. Welfare and macroeconomic interdependence. Quarterly Journal of Economics, 116(2):421-445, May 2001.

Dean Croushore and Charles L. Evans. Data revisions and the identification of monetary policy shocks. Journal of Monetary Economics, forthcoming.

Martin Eichenbaum and Charles L. Evans. Some empirical evidence on the effects of shocks to monetary policy on exchange rates. Quarterly Journal of Economics, 110(4): 975-1009, November 1995.

Charles Engel and Jeffrey Frankel. Why interest rates react to money announcements: An explanation from the foreign exchange market. Journal of Monetary Economics, 13(1):31-39, January 1984.

Jon Faust and John H. Rogers. Monetary policy's role in exchange rate behavior. Journal of Monetary Economics, 50:1403-1424, 2003.

Jon Faust, John H. Rogers, Eric Swanson, and Jonathan H. Wright. Identifying the effects of monetary policy shocks on exchange rates using high frequency data. Journal of the European Economic Association, 1(5):1031-1057, September 2003.

Milton Friedman and Anna Jacobson Schwartz. A Monetary History of the United States, 1867-1960. Princeton University Press, 1963.

Paolo Giordani. An alternative explanation of the price puzzle. Journal of Monetary Economics, 51(6):1271-1296, September 2004.

Soyoung Kim. International transmission of U.S. monetary policy shocks: Evidence from VARs. Journal of Monetary Economics, 48:339-372, 2001.

Soyoung Kim and Nouriel Roubini. Exchange rate anomalies in the industrial countries: A solution with a structural VAR approach. Journal of Monetary Economics, 45: 561-586, 2000. 
Kenneth N. Kuttner. Monetary policy surprises and interest rates: Evidence from the fed funds futures market. Journal of Monetary Economics, 47(3):523-544, June 2001.

Richard A. Meese and Kenneth Rogoff. Empirical exchange rate models of the Seventies: Do they fit out of sample? Journal of International Economics, 14(1-2):3-24, February 1983.
Ann-Marie Meulendyke. U.S. Monetary Policy and Financial Mar- kets. Federal Reserve Bank of New York, 1998. URL http://www.ny.frb.org/education/addpub/monpol/.

Maurice Obstfeld and Kenneth Rogoff. Exchange rate dynamics redux. Journal of Political Economy, 102:624-660, June 1995.

Maurice Obstfeld and Kenneth Rogoff. Foundations of International Macroeconomics. MIT Press, Cambridge, Massachusetts, first edition, 1996.

Adrian R. Pagan. Econometric issues in the analysis of regressions with generated regressors. International Economic Review, 25:221-248, 1984.

Christina D. Romer and David H. Romer. Does monetary policy matter? A new test in the spirit of Friedman and Schwartz. In Olivier Blanchard and Stanley Fischer, editors, 1989 NBER Macroeconomics Annual, pages 121-170. MIT Press, Cambridge, MA, 1989.

Christina D. Romer and David H. Romer. Federal Reserve information and the behavior of interest rates. American Economic Review, 90(3):429-457, June 2000.

Christina D. Romer and David H. Romer. A new measure of monetary shocks: Derivation and implications. American Economic Review, 94(4):1055-1084, September 2004.

Christopher A. Sims. Macroeconomics and reality. Econometrica, 48(1):1-48, January 1980.

Christopher A. Sims. Interpreting the macroeconomic time series facts: The effects of monetary policy. European Economic Review, 36(5):975-1000, June 1992. 
Figure 1:

\section{U.S. Interest Rate Measure} (over time)

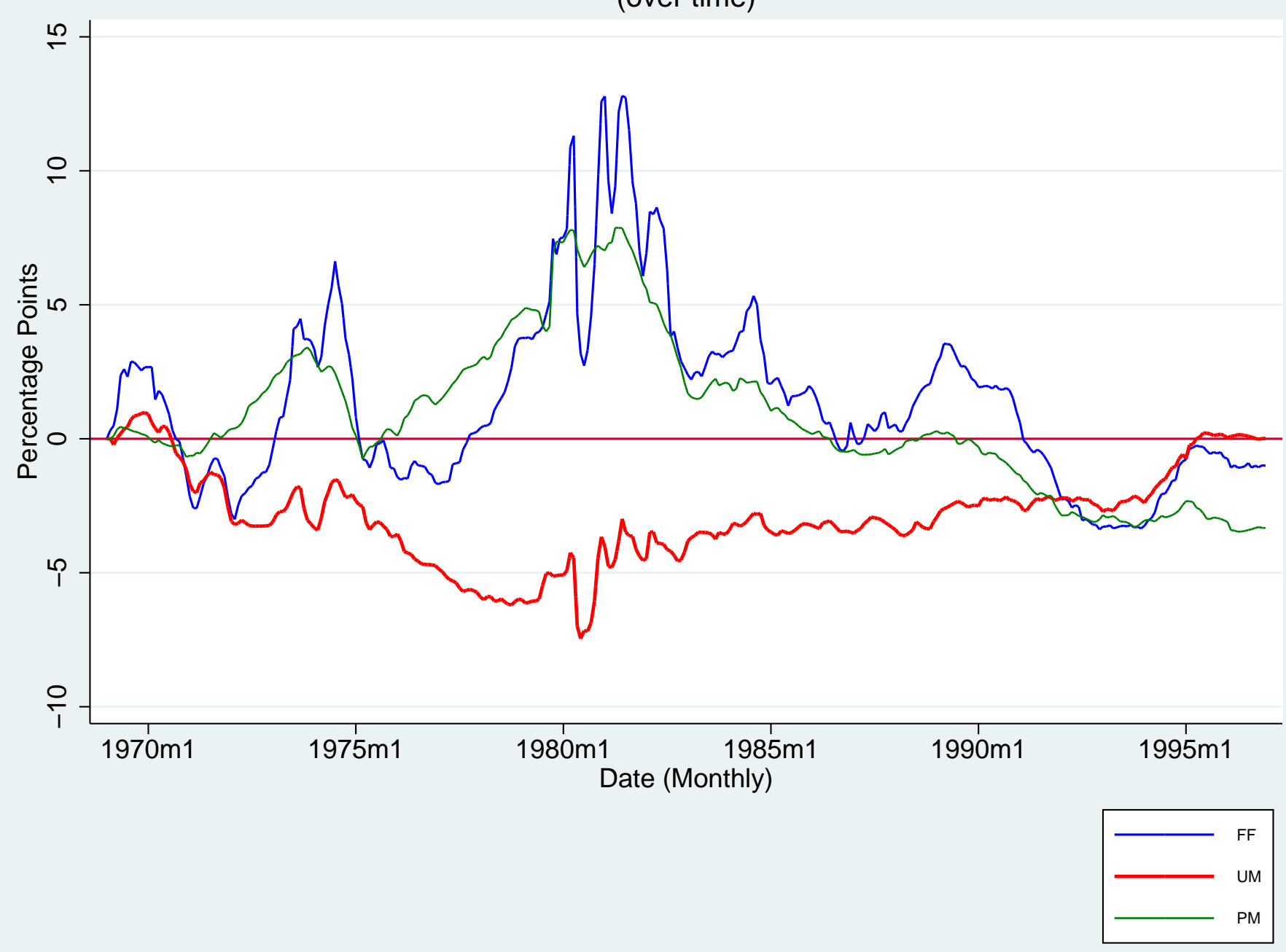


Figure 2:

\section{Bilateral Open Economy VAR Impulse Response \\ Bilateral Exchange Rate (US\$/.)}
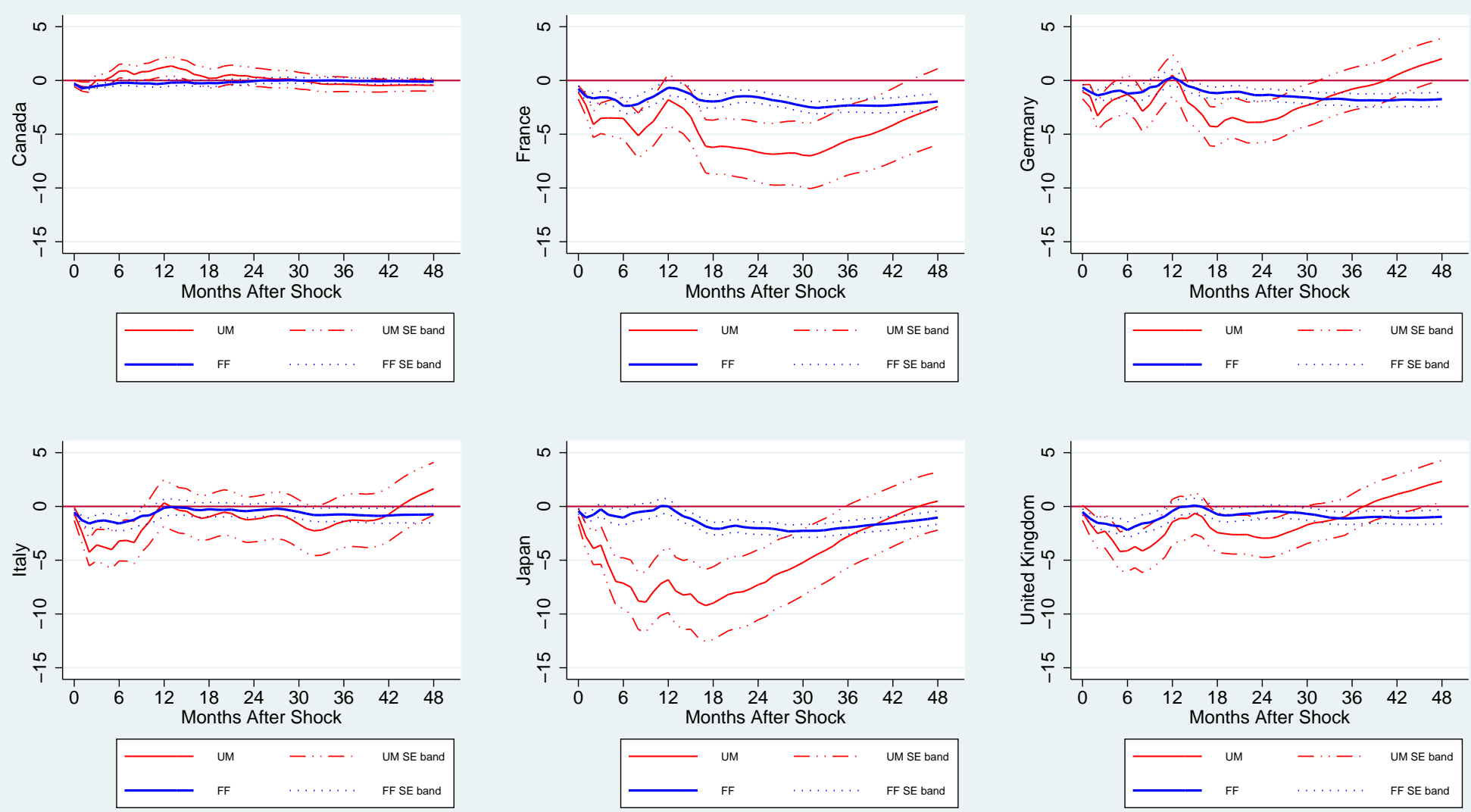

Note: Experiment is a 1 percentage point temporary increase in US interest rate measure.

All responses are in percentage points. Standard errors are calculated via delta-method.

System is ordered as $\left[y, p, y^{*}, p^{*}, r, r^{*}, s\right]$. 
Figure 3:

\section{Bilateral Open Economy VAR Impulse Response}

\section{Foreign Interbank Rate}
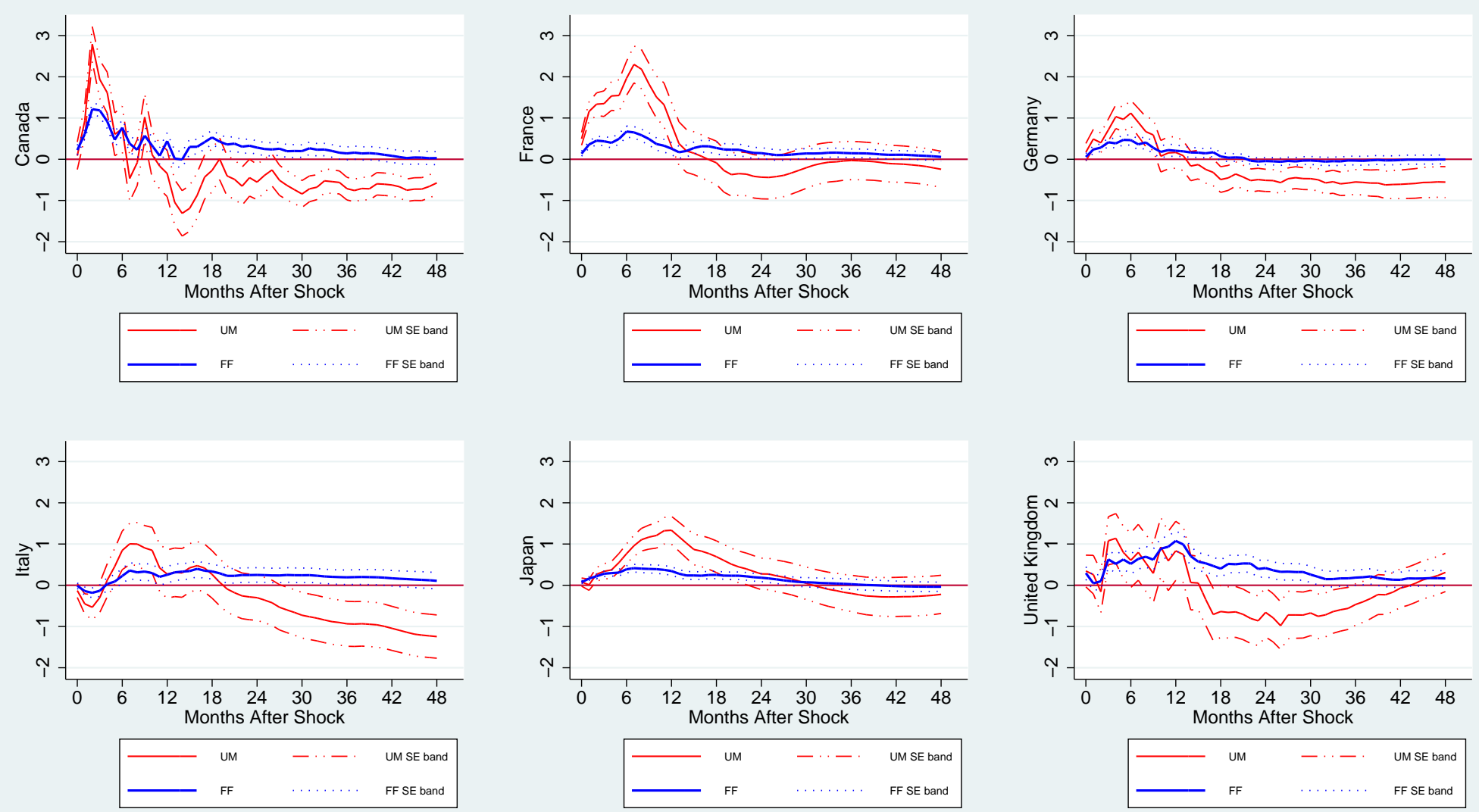

Note: Experiment is a 1 percentage point temporary increase in US interest rate measure.

All responses are in percentage points. Standard errors are calculated via delta-method.

System is ordered as $\left[y, p, y^{*}, p^{\star}, r, r^{*}, s\right]$. 
Figure 4:

\section{Bilateral Open Economy VAR Impulse Response}

Foreign Industrial Production Index
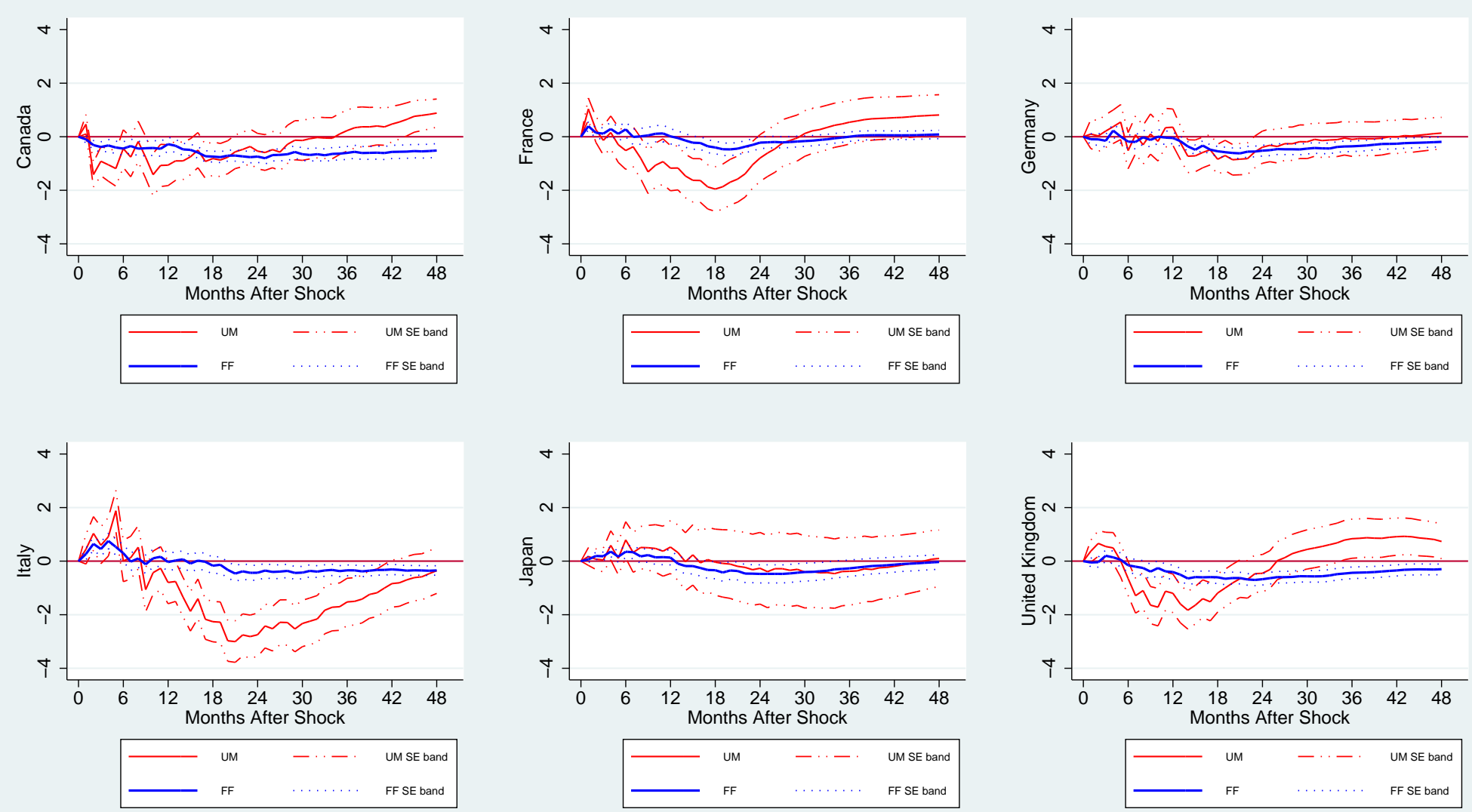

Note: Experiment is a 1 percentage point temporary increase in US interest rate measure.

All responses are in percentage points. Standard errors are calculated via delta-method.

System is ordered as $\left[y, p, y^{*}, p^{*}, r, r^{*}, s\right]$. 
Figure 5:

\section{Bilateral Open Economy VAR Impulse Response}

\section{Foreign CPI}
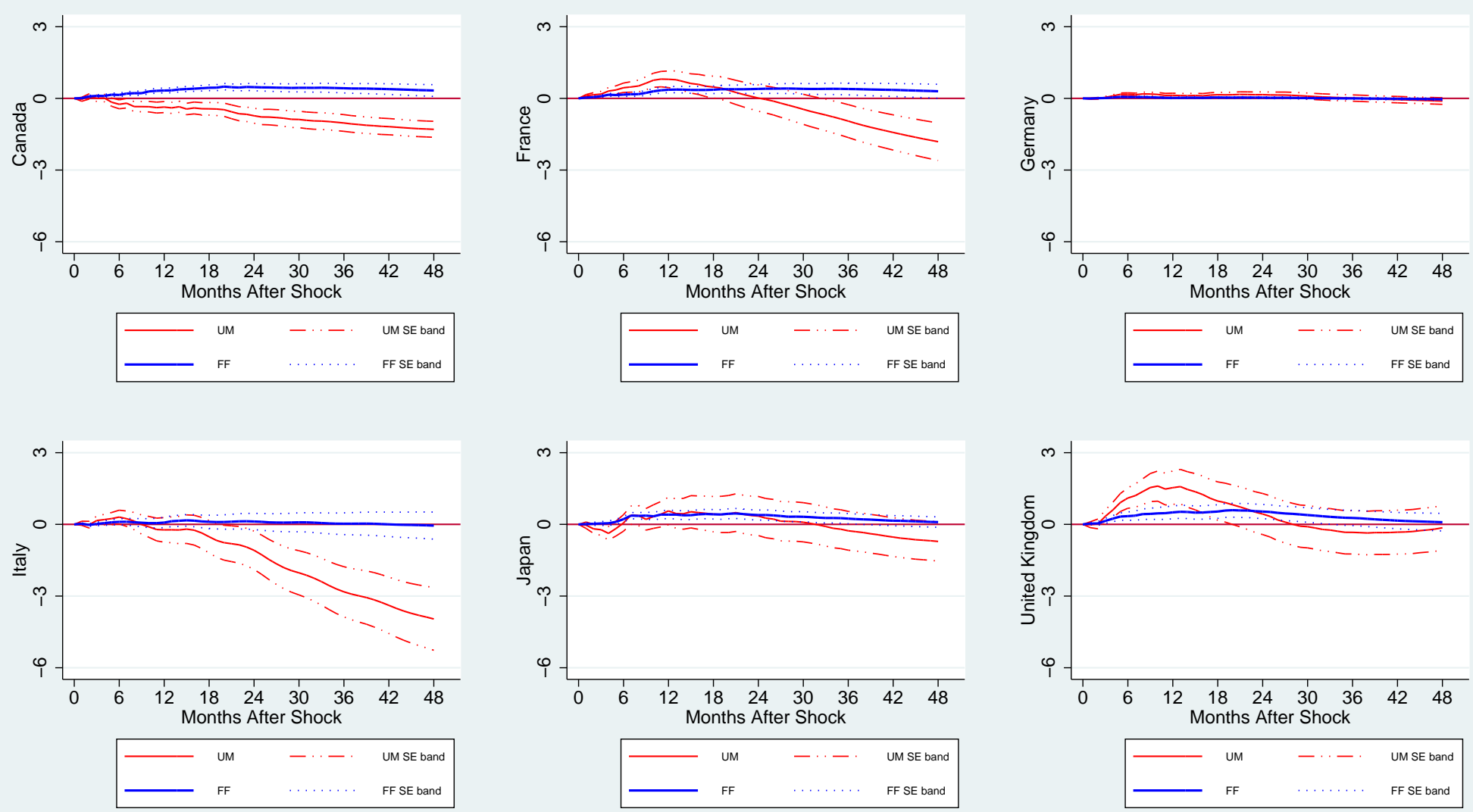

Note: Experiment is a 1 percentage point temporary increase in US interest rate measure.

All responses are in percentage points. Standard errors are calculated via delta-method.

System is ordered as $\left[y, p, y^{*}, p^{\star}, r, r^{*}, s\right]$. 
Figure 6:

\section{Bilateral Open Economy VAR Impulse Response US Industrial Production Index}
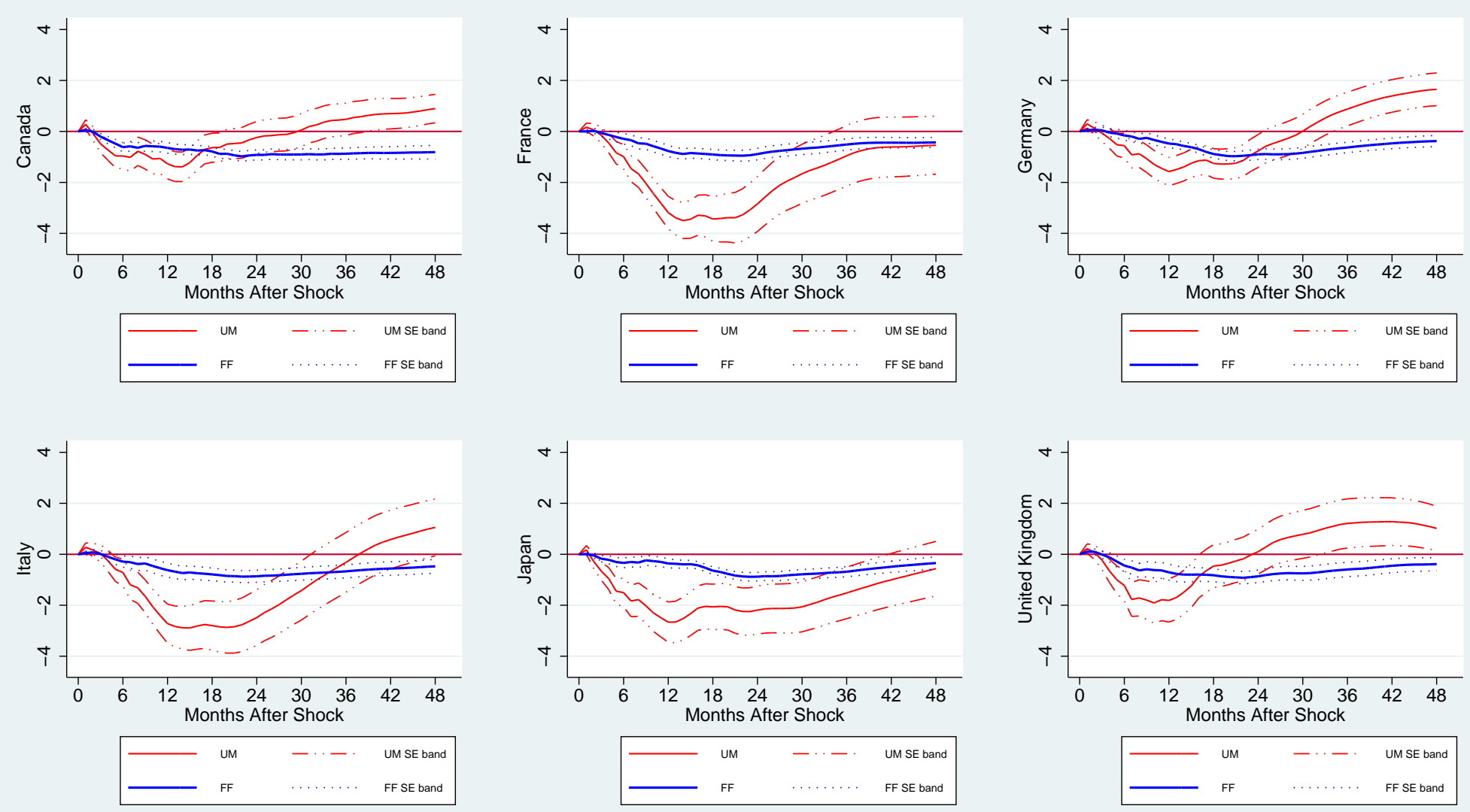

Note: Experiment is a 1 percentage point temporary increase in US interest rate measure.

All responses are in percentage points. Standard errors are calculated via delta-method.

System is ordered as $\left[y, p, y^{*}, p^{*}, r, r^{*}, s\right]$. 
Figure 7:

\section{Bilateral Open Economy VAR Impulse Response US CPI}
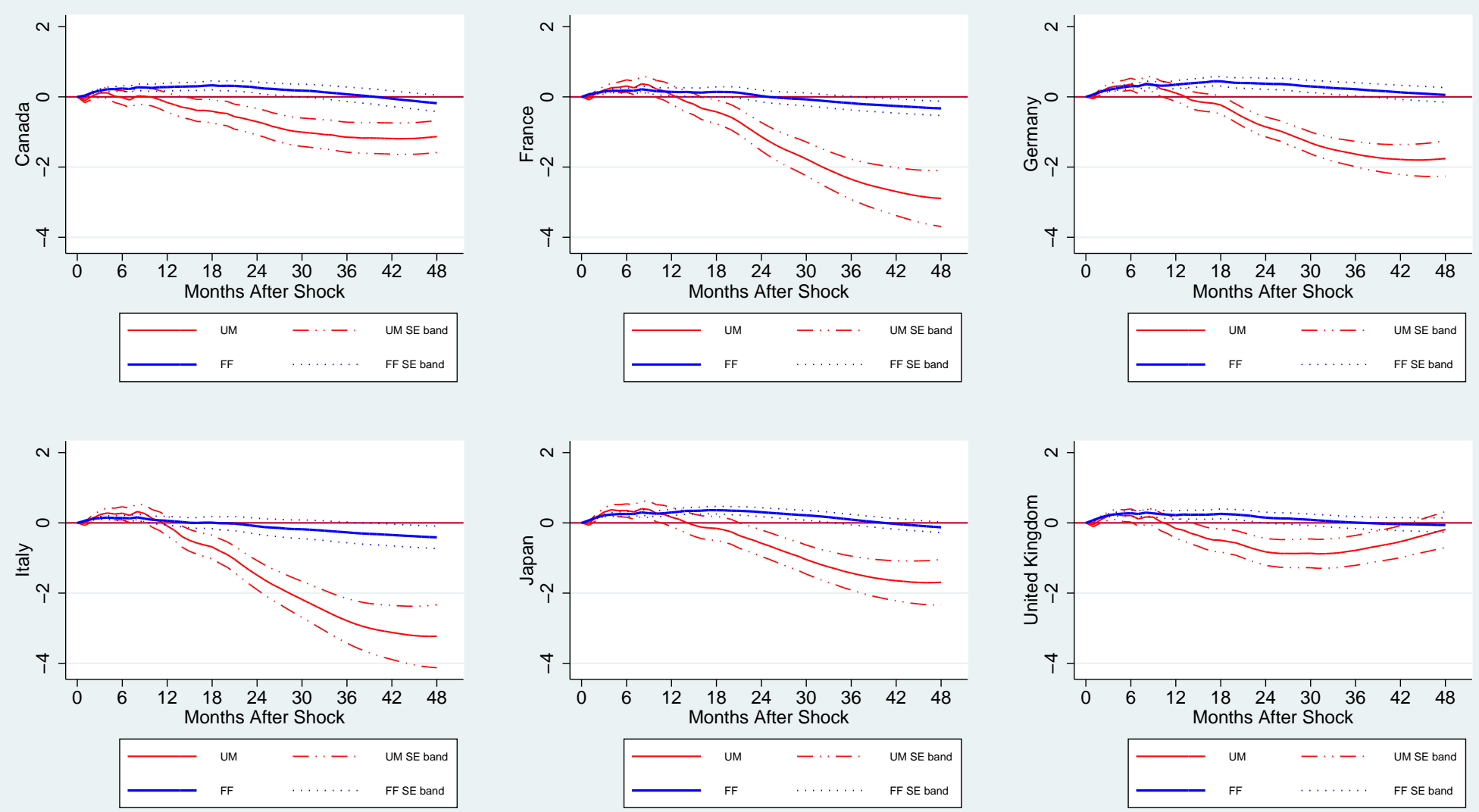

Note: Experiment is a 1 percentage point temporary increase in US interest rate measure.

All responses are in percentage points. Standard errors are calculated via delta-method.

System is ordered as $\left[y, p, y^{*}, p^{\star}, r, r^{*}, s\right]$. 
Figure 8:

\section{Bilateral Open Economy VAR Impulse Response}

\section{U.S. Predictable Monetary Policy Rate}
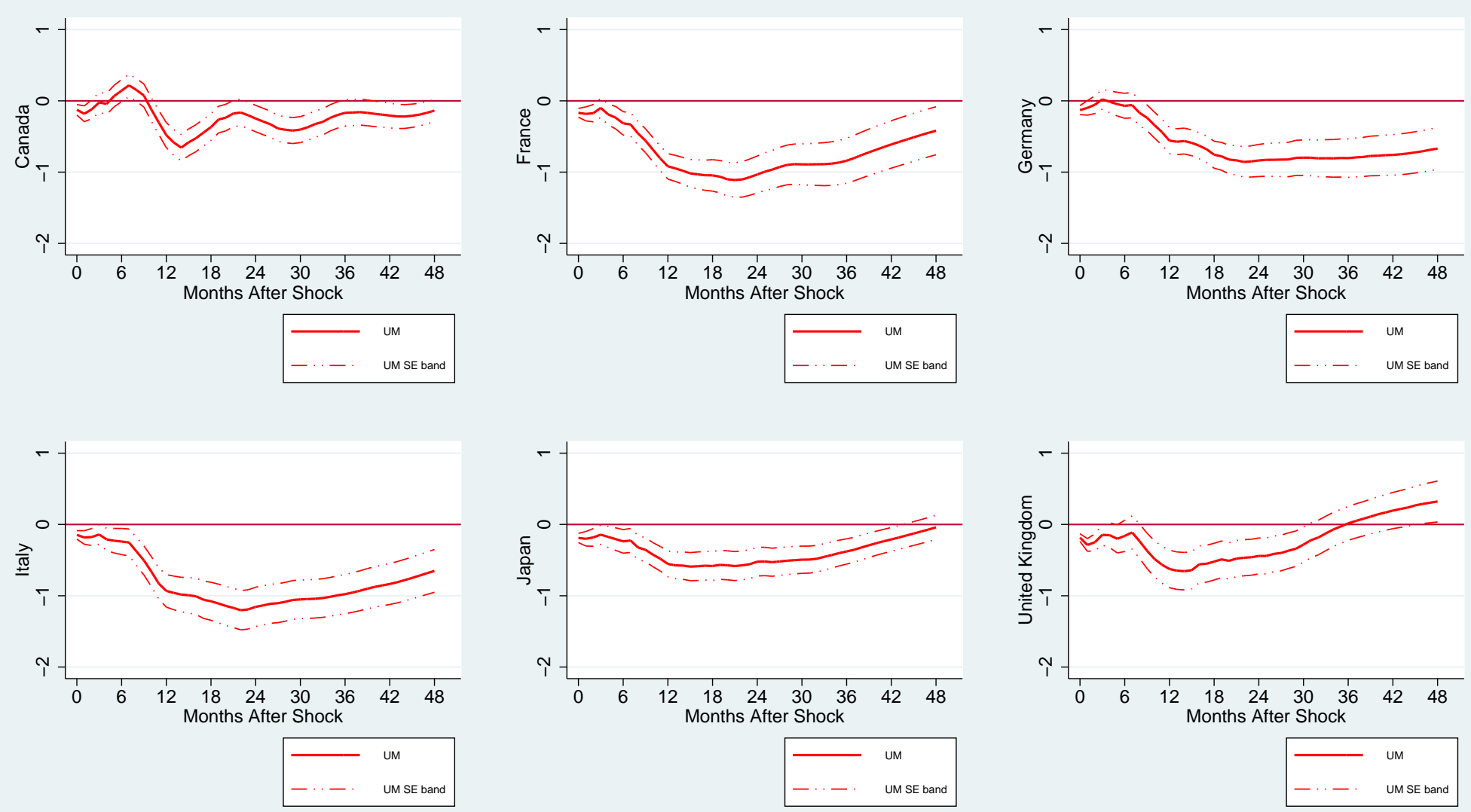

Note: Experiment is a 1 percentage point temporary increase in US interest rate measure.

All responses are in percentage points. Standard errors are calculated via delta-method.

System is ordered as $\left[y, p, y^{*}, p^{*}, U M, P M, r^{*}, s\right]$. 
Table 1:

\begin{tabular}{|c|c|c|c|c|c|}
\hline \multicolumn{6}{|c|}{ Maximum exchange rate responses } \\
\hline & & \multicolumn{2}{|l|}{12 Month Horizon } & \multicolumn{2}{|l|}{48 Month Horizon } \\
\hline Country & $\mathrm{FF} / \mathrm{UM}$ & Maximum response (t-ratio) & Timing & Maximum response (t-ratio) & Timing \\
\hline \multirow[t]{2}{*}{ Canada } & $\mathrm{FF}$ & $0.73(4.72)$ & 1 & $0.73(4.72)$ & 1 \\
\hline & UM & $-1.23(1.40)$ & 12 & $-1.35(1.54)$ & 13 \\
\hline \multirow[t]{2}{*}{ France } & $\mathrm{FF}$ & $2.36(3.28)$ & 6 & $2.55(4.51)$ & 32 \\
\hline & $\mathrm{UM}$ & $5.13(2.43)$ & 8 & $7.00(2.30)$ & 31 \\
\hline \multirow[t]{2}{*}{ Germany } & $\mathrm{FF}$ & $1.39(2.70)$ & 2 & $1.86(2.98)$ & 41 \\
\hline & UM & $3.30(2.51)$ & 2 & $4.31(2.35)$ & 18 \\
\hline \multirow[t]{2}{*}{ Italy } & $\mathrm{FF}$ & $1.59(3.18)$ & 2 & $1.59(3.18)$ & 2 \\
\hline & UM & $4.26(3.35)$ & 2 & $4.26(3.35)$ & 2 \\
\hline \multirow[t]{2}{*}{ Japan } & $\mathrm{FF}$ & $1.05(2.55)$ & 1 & $2.31(3.93)$ & 28 \\
\hline & UM & $8.90(3.20)$ & 9 & $9.21(2.74)$ & 17 \\
\hline \multirow[t]{2}{*}{ UK } & $\mathrm{FF}$ & $2.19(2.89)$ & 6 & $2.19(2.89)$ & 6 \\
\hline & $\mathrm{UM}$ & $4.19(2.29)$ & 5 & $4.19(2.29)$ & 5 \\
\hline \multicolumn{6}{|c|}{ Maximum foreign interest rate responses } \\
\hline \multirow[t]{2}{*}{ Canada } & $\mathrm{FF}$ & $1.22(9.09)$ & 2 & $1.22(9.09)$ & 2 \\
\hline & UM & $2.79(6.58)$ & 2 & $2.79(6.58)$ & 2 \\
\hline \multirow[t]{2}{*}{ France } & $\mathrm{FF}$ & $0.67(5.03)$ & 6 & $0.67(5.03)$ & 6 \\
\hline & UM & $2.30(5.15)$ & 7 & $2.30(5.15)$ & 7 \\
\hline \multirow[t]{2}{*}{ Germany } & $\mathrm{FF}$ & $0.47(3.97)$ & 5 & $0.47(3.97)$ & 5 \\
\hline & UM & $1.12(3.61)$ & 6 & $1.12(3.61)$ & 6 \\
\hline \multirow[t]{2}{*}{ Italy } & $\mathrm{FF}$ & $0.36(1.87)$ & 7 & $0.40(2.10)$ & 16 \\
\hline & UM & $1.00(2.02)$ & 7 & $-1.24(2.37)$ & 48 \\
\hline \multirow[t]{2}{*}{ Japan } & $\mathrm{FF}$ & $0.41(4.48)$ & 7 & $0.41(4.48)$ & 7 \\
\hline & UM & $1.34(3.95)$ & 12 & $1.34(3.95)$ & 12 \\
\hline \multirow[t]{2}{*}{ UK } & $\mathrm{FF}$ & $1.08(4.43)$ & 12 & $1.08(4.43)$ & 12 \\
\hline & UM & $1.14(1.89)$ & 4 & $1.14(1.89)$ & 4 \\
\hline
\end{tabular}

Notes: Maximum responses refer to the largest absolute change in the US\$ and the foreign interest rate within 12 and 48 month intervals following a 100 basis point increase in US interest rates. The units are percentage points. In the exchange rate panel positive numbers denote appreciation. The tratios are calculated using the delta method. Timing indicates the number of months after which a maximum occurs. 
Table 2:

\begin{tabular}{|c|c|c|c|c|c|}
\hline \multicolumn{6}{|c|}{ Maximum foreign output responses } \\
\hline & & \multicolumn{2}{|l|}{12 Month Horizon } & \multicolumn{2}{|l|}{48 Month Horizon } \\
\hline Country & $\mathrm{FF} / \mathrm{UM}$ & Maximum response (t-ratio) & Timing & Maximum response (t-ratio) & Timing \\
\hline \multirow[t]{2}{*}{ Canada } & $\mathrm{FF}$ & $-0.45(1.63)$ & 11 & $-0.80(3.72)$ & 25 \\
\hline & UM & $-1.42(1.80)$ & 10 & $-1.42(1.80)$ & 10 \\
\hline \multirow{2}{*}{ France } & FF & $0.40(2.47)$ & 1 & $-0.47(2.04)$ & 20 \\
\hline & UM & $-1.31(1.62)$ & 9 & $-1.95(2.34)$ & 18 \\
\hline \multirow[t]{2}{*}{ Germany } & FF & $0.23(0.96)$ & 4 & $-0.62(3.19)$ & 21 \\
\hline & UM & $0.55(0.84)$ & 5 & $-0.86(1.50)$ & 20 \\
\hline \multirow[t]{2}{*}{ Italy } & $\mathrm{FF}$ & $0.76(2.66)$ & 4 & $0.76(2.66)$ & 4 \\
\hline & UM & $1.88(2.48)$ & 5 & $-3.00(3.88)$ & 21 \\
\hline \multirow[t]{2}{*}{ Japan } & $\mathrm{FF}$ & $0.36(1.91)$ & 4 & $-0.48(1.41)$ & 27 \\
\hline & UM & $0.79(1.17)$ & 6 & $0.79(1.17)$ & 6 \\
\hline \multirow[t]{2}{*}{ UK } & $\mathrm{FF}$ & $-0.40(1.58)$ & 12 & $-0.70(3.25)$ & 23 \\
\hline & $\mathrm{UM}$ & $-1.72(2.46)$ & 10 & $-1.83(2.61)$ & 14 \\
\hline \multicolumn{6}{|c|}{ Maximum foreign price level responses } \\
\hline \multirow[t]{2}{*}{ Canada } & $\mathrm{FF}$ & $0.33(3.27)$ & 12 & $0.49(3.73)$ & 20 \\
\hline & UM & $-0.39(1.69)$ & 11 & $-1.29(3.88)$ & 48 \\
\hline \multirow[t]{2}{*}{ France } & $\mathrm{FF}$ & $0.36(2.86)$ & 12 & $0.41(1.97)$ & 28 \\
\hline & UM & $0.81(2.50)$ & 11 & $-1.81(2.30)$ & 48 \\
\hline \multirow[t]{2}{*}{ Germany } & $\mathrm{FF}$ & $0.06(2.88)$ & 5 & $0.06(2.88)$ & 5 \\
\hline & UM & $0.19(2.56)$ & 8 & $0.19(2.56)$ & 8 \\
\hline \multirow[t]{2}{*}{ Italy } & $\mathrm{FF}$ & $0.11(0.78)$ & 7 & $0.17(0.70)$ & 15 \\
\hline & UM & $0.31(1.06)$ & 6 & $-3.96(3.03)$ & 48 \\
\hline \multirow[t]{2}{*}{ Japan } & $\mathrm{FF}$ & $0.41(2.43)$ & 11 & $0.46(2.20)$ & 21 \\
\hline & UM & $0.56(0.97)$ & 12 & $-0.71(0.87)$ & 48 \\
\hline \multirow[t]{2}{*}{ UK } & FF & $0.50(1.87)$ & 12 & $0.59(2.05)$ & 20 \\
\hline & UM & $1.60(2.54)$ & 10 & $1.60(2.54)$ & 10 \\
\hline
\end{tabular}

Notes: Maximum responses refer to the largest absolute changes in foreign output and the foreign price level within 12 and 48 month intervals following a 100 basis point increase in US interest rates. The units are percentage points. The t-ratios are calculated using the delta method. Timing indicates the number of months after which a maximum occurs. 


\section{A Appendix}

Table A.1:

\begin{tabular}{|c|c|c|c|}
\hline \multicolumn{4}{|c|}{ Residual diagnostics for VAR models } \\
\hline \multicolumn{4}{|c|}{ Foreign country: Canada } \\
\hline Equation & $\operatorname{AR}(1-7)$ & Heteroscedasticity & Normality \\
\hline $\bar{y}$ & 0.412 & 0.424 & 0.75 \\
\hline $\mathrm{p}$ & 0.972 & 0.51 & 0.232 \\
\hline $\mathrm{y}^{*}$ & 0.049 & 0.402 & 0 \\
\hline $\mathrm{p}^{*}$ & 0.175 & 0.929 & 0 \\
\hline $\mathrm{r}$ & 0.046 & 0.11 & 0 \\
\hline $\mathrm{r}^{*}$ & 0.917 & 0.119 & 0 \\
\hline $\mathrm{s}$ & 0.311 & 0.742 & 0.929 \\
\hline \multicolumn{4}{|c|}{ Foreign country: France } \\
\hline Equation & $\operatorname{AR}(1-7)$ & Heteroscedasticity & Normality \\
\hline $\mathrm{y}$ & 0.37 & 1 & 0.076 \\
\hline $\mathrm{p}$ & 0.377 & 1 & 0 \\
\hline $\mathrm{y}^{*}$ & 0.689 & 1 & 0 \\
\hline $\mathrm{p}^{*}$ & 0.643 & 1 & 0 \\
\hline $\mathrm{r}$ & 0.003 & 1 & 0 \\
\hline $\mathrm{r}^{*}$ & 0.3 & 1 & 0 \\
\hline $\mathrm{s}$ & 0.319 & 1 & 0.321 \\
\hline \multicolumn{4}{|c|}{ Foreign country: Germany } \\
\hline Equation & $\operatorname{AR}(1-7)$ & Heteroscedasticity & Normality \\
\hline $\bar{y}$ & 0.627 & 1 & 0.002 \\
\hline $\mathrm{p}$ & 0.013 & 0.998 & 0.5 \\
\hline $\mathrm{y}^{*}$ & 0.375 & 1 & 0 \\
\hline $\mathrm{p}^{*}$ & 0.712 & 1 & 0 \\
\hline $\mathrm{r}$ & 0 & 1 & 0 \\
\hline $\mathrm{r}^{*}$ & 0.056 & 0.748 & 0 \\
\hline $\mathrm{s}$ & 0.611 & 1 & 0.153 \\
\hline
\end{tabular}

Notes: The figures reported are p-values from the following tests: $\operatorname{AR}(1-7)$ is an F-test of the hypothesis that the errors are serially uncorrelated at lags 17. Heteroscedasticity is an F-test of unconditional homoscedasticity in the errors, and Normality a Jarque-Bera test of normality of the errors. 
Table A.1: continued

\begin{tabular}{|c|c|c|c|}
\hline \multicolumn{4}{|c|}{ Residual diagnostics for VAR models } \\
\hline \multicolumn{4}{|c|}{ Foreign country: Italy } \\
\hline Equation & $\operatorname{AR}(1-7)$ & Heteroscedasticity & Normality \\
\hline $\mathrm{y}$ & 0.212 & 1 & 0.001 \\
\hline $\mathrm{p}$ & 0.074 & 1 & 0.001 \\
\hline $\mathrm{y}^{*}$ & 0.098 & 0.988 & 0 \\
\hline $\mathrm{p}^{*}$ & 0.553 & 0.994 & 0 \\
\hline $\mathrm{r}$ & 0.165 & 1 & 0 \\
\hline $\mathrm{r}^{*}$ & 0.521 & 1 & 0 \\
\hline $\mathrm{s}$ & 0.307 & 1 & 0.01 \\
\hline \multicolumn{4}{|c|}{ Foreign country: Japan } \\
\hline Equation & $\operatorname{AR}(1-7)$ & Heteroscedasticity & Normality \\
\hline $\bar{y}$ & 0.806 & 1 & 0.362 \\
\hline $\mathrm{p}$ & 0.33 & 1 & 0 \\
\hline $\mathrm{y}^{*}$ & 0.479 & 1 & 0.173 \\
\hline $\mathrm{p}^{*}$ & 0.734 & 0.866 & 0 \\
\hline $\mathrm{r}$ & 0.177 & 1 & 0 \\
\hline$r^{*}$ & 0.894 & 1 & 0 \\
\hline $\mathrm{s}$ & 0.412 & 1 & 0.002 \\
\hline \multicolumn{4}{|c|}{ Foreign country: UK } \\
\hline Equation & $\operatorname{AR}(1-7)$ & Heteroscedasticity & Normality \\
\hline $\mathrm{y}$ & 0.101 & 1 & 0.236 \\
\hline $\mathrm{p}$ & 0.313 & 1 & 0 \\
\hline $\mathrm{y}^{*}$ & 0.2 & 1 & 0 \\
\hline $\mathrm{p}^{*}$ & 0.373 & 1 & 0 \\
\hline $\mathrm{r}$ & 0.102 & 0.953 & 0 \\
\hline $\mathrm{r}^{*}$ & 0.608 & 1 & 0 \\
\hline $\mathrm{S}$ & 0.56 & 1 & 0.009 \\
\hline
\end{tabular}

Notes: The figures reported are p-values from the following tests: $\operatorname{AR}(1-7)$ is an F-test of the hypothesis that the errors are serially uncorrelated at lags 17. Heteroscedasticity is an F-test of unconditional homoscedasticity in the errors, and Normality a Jarque-Bera test of normality in the errors. 
Table A.2:

Data sources

\begin{tabular}{ll}
\hline \hline Variable & Source \\
\hline $\begin{array}{l}\text { Bilateral dollar } \\
\text { exchange rates }\end{array}$ & Board of Governors of the Federal Reserve System \\
& $\begin{array}{l}\text { Foreign exchange releases } \\
\text { URL: federalreserve.gov/releases/h10/Hist/ }\end{array}$ \\
\hline Consumer prices & International Financial Statistics, line $64 \ldots$ ZF \\
\hline Industrial production & International Financial Statistics, line $66 \ldots$ CZF \\
\hline Foreign interest rates & International Financial Statistics, line $60 \mathrm{~B} \mathrm{\ldots ..} \mathrm{ZF}$ \\
\hline Federal funds rate & AER data archive \\
& URL: www.e-aer.org/data \\
\hline Intended, unanticipated federal funds & AER data archive \\
rate changes at FOMC meetings & URL: www.e-aer.org/data \\
\hline World commodity prices & AER data archive \\
& URL: www.e-aer.org/data \\
\hline
\end{tabular}

